\title{
Professionals' satisfaction and Dissatisfaction with LIS Curricula in Pakistan
}

\author{
Farhat Hussain* \\ Munira Nasreen Ansari**
}

\begin{abstract}
This paper explores the opinion of junior and senior library professionals working for various organizations in Pakistan on LIS curricula and seeks their suggestions to develop an effective and practicable curriculum. Survey research method was used to collect data from professionals through a structured questionnaire. The findings reveal that the LIS curricula offered by the library schools of Pakistan are not up to mark and flaws are observed everywhere, hence not meeting the challenges of the profession. But, to a large extent, the respondents were satisfied with the contents of the curricula with some reservations and apprehensions. They also gave some suggestions to modify and upgrade the curriculum to make it compatible with the market requirements. They also proposed to revise the curriculum periodically after taking the professionals working in the field in confidence.
\end{abstract}

Keywords: LIS education; Curriculum; Pakistan; Library Schools; Curriculum Development

*Assistant Professor, Department of Library and Information Science, University of Karachi.

**Associate Professor, Department of Library and Information Science, University of Karachi. 


\section{Introduction}

Education is a key element in progress and change not only for individuals but for the society. It occupies a prominent position in every modern human society. Any education system possesses a strategy that reflects its nation's belief and supports its national character. (Mallinson ${ }^{1}$ ). The aim of education is to make a person intelligent enough to take decisions logically and knowledgeably. Today, a large number of career options are available to the youths and a number of institutes and organizations are offering variety of jobs to the candidates to choose the right one. Getting a professional education is important for shaping career to move towards a right direction. Especially in developing countries, professional education is of great importance. Medical, engineering, dentistry, teaching, business management, accounting, librarianship, advocacy, media, forestry and nursing are some of the professional careers and the list, by no means, is complete.

Despite the importance and skillfulness of the librarians especially in the field of research, yet in some Asian countries, they are still not given that status and importance which they are worthy of. The reason behind this ignorance and lack of acknowledgement and thanklessness may be the lack of demands of information needs by the people of the society. In Pakistan, library professionals are not getting the due status which they deserve because they are not that much active in marketing their profession's value as well as in offering modern services. The libraries and librarianship can get a status and prestige like the ones of developed countries do if there is pliancy in the education systems, major emphasis is given to research, imparting in-service training, equipping the serving departments with latest facilities, employing new and skilled personnel, stimulating collaboration among faculty and departments, creating diversity in courses and degrees, updating syllabi on continuous basis, making the most of ICT, and originating as well as publishing LIS literature in national and local languages.

"No doubt, it is the curriculum and courses which are producing competent professionals. For any educational and learning program, curriculum is very essential not only by providing course's list or offered module in a programme, but essentially by conferring learning and education to the

1 Mallinson, Vernon. The Western European idea in education. European journal of education. 16(1), 1981. pp. 121-128. 
practitioners through information over layout, objective, procedures, duration/time, learners and situation and of a programme or course". $\left(\right.$ Ocholla $^{2}$ ). Curriculum models contain the designing and the actions, the resources' support and the examination required. They are primarily layout to give undeviating educational methods and anticipated outcomes of students. The level of flexibility in curriculum models varies that is provided to educators. Few curriculum models provide teachers a detailed script to proceed while others outline the principles providing an open path to make the best use of these principles over the students. Even some schools modify these curriculum models as per the needs and trends of local market.

According to Curry ${ }^{3}$, the status of programmes need to be improvised that required struggles to be made by LIS education and training. At one side it is important to make them able to serve in educational networks as well as developing new strategies for the proposing and implementing LIS education while at the other side, to produce graduate where work place spans the whole world.

According to Mangla ${ }^{4}$ library and information science programmes should be so designed as to equip the students with knowledge and techniques to handle the immediate job requirements in an efficient manner; and to develop programmes, procedures and services on modern lines in future where the use of various modern techniques, computers etc. could provide better, quicker and efficient service. From the above, there is a keen requirement to take a global view at the curricula of library and information science. Presently, the diversity of information work must be a requisite in the formal education provided to information professionals. Thus, many programmes are now generalized at a high extend, by providing a range of generic and specific skills, along with the information management principles for creating an understanding and making visible multiple professional career path for LIS graduates.

2 Ocholla, D.N. Review and revision of library and information science curriculum in South Africa University and usage of follow-up study and advancement scanning methods, 2000. Available: http://www.slib.ualberta.ca/cais/2000/ocholla.htm

3 Curry, A. Canadian library and information science education trends and issues. Education for Information, 18 (4), 2002. pp. 325-337.

4 Mangla, P.B. Contents and courses at the postgraduate level. Journal of Library and Information Science. 5(2), 1980. p.102. 


\section{Objective}

This study endeavors to analyze and evaluate comprehensively the courses of study being taught in different library schools of Pakistan. To meet the target, the study is:

> To find out the number and titles of courses being taught in a year/semester.

$>$ To find out the number and titles of compulsory and elective courses.

$>$ To seek opinions of respondents about suitability of a professional with different courses studied.

$>$ To know how much the respondents are satisfied with the course content.

$>$ To pursue views about the possibility of merging two or more courses.

$>$ To strive for recommendations about needed competencies.

\section{Literature Review}

Adequate literature is available on different aspects of the courses and curricula of library and information science taught at the universities of Pakistan. To avoid duplication or similarity, literature review has been confined to unique and important information about the objectives of the study, so the literature on LIS Curricula in Pakistan is reviewed.

Khan and Mahmood ${ }^{5}$ compare Pakistan LIS School's curricula with HECdesigned curriculum for LIS schools in Pakistan. The paper identifies the most common course titles and the most unique course titles taught in Pakistani universities' Library \& Information Science departments. The study reveals that standard and uniformity is entirely neglected by the LIS schools of Pakistan. Courses in all library schools are offered according to their interest, causing problems for the graduates of these schools. The researchers are of the opinion that the paper helps to design LIS schools curricula keeping in view the societal needs and to identify the status of LIS schools at an international level

5 Khan, M. Tufail and Mahmood, Khalid. A comparison of MLIS curricula taught in Pakistani library and information science schools with Higher Education Commission curriculum. Library Philosophy and Practice (e-journal). 2013. retrieved on 15-10-2013. 
Mahmood $^{6}$ studies LIS curriculum for seeking feedback of the senior librarians and employers of young librarians. He observes that the library practitioners had reservations on the quality of education, asserting the lacking pace of library schools in comparison to the technological and environmental developments growing rapidly in libraries. The findings reveal that "Competencies required of an LIS graduate can be divided into three categories: LIS core, management, and ICTs. All three areas should be given a balanced importance in the curriculum.

Warraich $^{7}$ analyzed the curriculum of MLIS at University of Punjab and conducted a survey on the alumni of the department to find out their satisfaction about the curricula they studied. Some of the problems or deficiencies pointed out in the survey include: Non-proficiency in written and spoken English, lack of knowledge of office communication, lack of interviewing skills, unawareness of advanced library softwares, lack of IT skills, poor interpersonal skills, lack of leadership skills, weak presentation skills, lack of research skills etc. The respondents suggested that if these shortcomings are removed and are incorporated in the curriculum, the alumni will get better job opportunities and will compete the market.

Discussing the merits and demerits of the courses of Library Management taught by all the library schools of Pakistan, Ameen ${ }^{8}$ observes that library leadership is almost an unfamiliar area in library and information science (LIS) education. The paper identifies rudimentary attributes of leadership required for LIS professionals and status of these professionals in Pakistan. Findings suggest that information professionals today require quality of leadership and anticipation to innovate the future through planning and preventing from unexpected changes in such emerging social, technological and professional scenario of the country.

6 Mahmood, Khalid. LIS curriculum review using focus group interviews of employers. Library philosophy and practice (e-journal). 2012. retrieved on 6-72012.

7 Warraich, Nosheen Fatima. MLIS curriculum at Punjab University: perception and reflections. Library Philosophy and Practice (e-journal.) 2010. retrieved on 19-3-2010.

8 Ameen, Kanwal. Challenges of preparing LIS professionals for leadership roles in Pakistan. Journal of education for Library and Information Science. 47(3).2006. pp. 200217. 
Haider ${ }^{9}$ analyzes six LIS Departments of the country with respect to their cataloging and classification courses' contents and teaching methodologies. The study reveals that in almost all library schools of the country, cataloging practices of the 1960s and 1970s dominate and it has not been modified. Same is the situation of classification practices. Suggestions comprise: curricula revision, organizing training of teachers for cataloging and classification courses in developed countries, improvement of laboratories, and the organization of continuing education programs.

Yusuf ${ }^{10}$ analyzed the courses offered in BLIS and MLIS in six library schools in Pakistan (Universities of Karachi, Baluchistan, Bahawalpur, Peshawar, Punjab and Sindh). The author opines that the library schools of Pakistan are producing traditional librarians so cannot meet the requirements of modern librarianship. After reviewing briefly the programs and courses of all six library schools of that time, succinct comments were given on the shortcomings in the curricula. Recommendations were made to include courses on communication techniques, statistics, research methods, networking databases, selective dissemination of information in the curricula of the universities.

Sabzwari ${ }^{11}$ discussed the situation of library education in Pakistan in detail. He reviewed the postgraduate courses in library schools in four universities of Pakistan which are Karachi, Punjab, Peshawar and Sindh Universities. With respect to curricula, he advised that at postgraduate diploma level (BLS, DLS, or M.A. Previous), specialization in the profession be offered and there should be an optional course of school, college or children librarianship and students should opt any one of them as per their interest or ability. At Masters (final) level, he suggested to include the courses which should fulfill the local market needs.

After going through the literature on LIS curricula in Pakistan, it is concluded that all the library schools of the country are offering courses of their own accord and needs and rarely there are one or two schools that are following the curriculum designed by HEC. The literature also gives some suggestions

9 Haider, S. J. Teaching of cataloging and classification in Pakistan. Cataloging \& classification quarterly, 43. 2006. pp. 53-65.

10 Yusuf, M. Critical view of the courses offered at library schools in Pakistan. PLA journal, 18. 1996. pp. 68-76.

11 Sabzwari, G.A. (1972). Library education and manpower needs in Pakistan. Pakistan library bulletin. IV(3-4). 1972. pp. 55-71. 
to maintain the international standard and to fulfill the market needs. The most important shortcomings which are pointed out in the curricula include non-adoption of technological and environmental development as the joboffering organizations find lack of knowledge and skills about the modern innovations especially ICT in the prospective candidates. Another deficiency is verbal and written English communication. Other deficiencies are unawareness about the latest library softwares and lack of leadership skills. To remove these shortcomings, enhance professional skills and to acquire better job opportunities, the curriculum should be revise and updated by incorporating the relevant topics.

\section{Research Methodology}

Data about various intended needs and competencies or deficiencies with respect to curricula was collected through questionnaires filled by the library professionals. Survey through questionnaire was conducted to investigate the local market requirements. The library professionals working in different types of libraries of all the provinces, Azad Kashmir, FATA, and federal capital Islamabad were approached to find out a variety of requirements. The survey was also aimed to realize the utility of the courses they studied and insignificance of some of the courses being offered at library schools. They were further probed to recommend the courses which can be merged.

The questionnaire was composed of following parts:

a) Demographic: It intends to seek information about the name (optional), designation, organization, type of library working in, working experience, name of the university studied in, highest professional degree obtained, and year of passing of the respondents.

b) Classified: It contains: i. Questions based on level of measurement ii. Dichotomous questions and iii. Open-ended questions

Besides demographic information, the other information sought from the participants were about the number of compulsory and elective courses they had studied, their opinion about suitability or unsuitability of a professional with different courses studied, utilization of theory courses in profession, their satisfaction with the course contents, opinion and inspiration about the courses of other universities, possibility of merging of two or more courses, opinion about the nature of Masters' thesis, and suggestions about needed competencies.

A total 300 questionnaires were distributed among the professionals of all four provinces and federal capital. Of them, 250 questionnaires were 
received back and it was a rigorous exercise to remind and pursue the respondents. The following table shows the representations of the participants from different provinces and federal capital of Pakistan:

Table 1: Participants of Survey Representing Provinces and Federal Capital

\begin{tabular}{|l|c|c|}
\hline $\begin{array}{c}\text { Province/Federal } \\
\text { Capital }\end{array}$ & $\begin{array}{c}\text { Frequency } \\
(\mathrm{N}=250)\end{array}$ & Percentage \\
\hline Punjab & 97 & $38.8 \%$ \\
\hline Khyber Pakhtoonkhwah & 67 & $26.8 \%$ \\
\hline Sindh & 46 & $18.4 \%$ \\
\hline Federal Capital, Islamabad & 24 & $9.6 \%$ \\
\hline Baluchistan & 16 & $6.4 \%$ \\
\hline
\end{tabular}

Of these 250 respondents who returned the filled questionnaires, the greatest number was of the graduates of different library schools of Punjab. This number was 97 which is $38.8 \%$ of total population. Similarly, the graduates of KPK, Sindh, Federal capital Islamabad, and Baluchistan were respectively $67(26.8 \%), 46(18.4 \%), 24(9.6 \%)$ and $16(6.4 \%)$. The majority of the graduates is working in the respective provinces with the exception of a few cases.

The data of questionnaires were statistically analyzed using SPSS (Statistical Package for the Social Science) computer software. Various statistical procedures used in the data analysis include Frequency distribution, and Descriptive statistics.

\section{Data Analysis and Interpretation}

Following is the analysis and interpretation of the data collected through questionnaire:

\section{Demographic Characteristics}

The targeted population of the ongoing research is library professionals working in different types of libraries in Pakistan covering all four provinces and federal capital Islamabad. 
Table 2 : Demographic characteristics of the participants

\begin{tabular}{|l|c|c|}
\hline Characteristics (Age) & Frequency $(\mathbf{N}=250)$ & Percentage \\
\hline Less than 31 years & 51 & 20.4 \\
\hline $\begin{array}{l}\text { Between 31 and 40 } \\
\text { years }\end{array}$ & 134 & 53.6 \\
\hline 41 years and above & 65 & 26.0 \\
\hline $\begin{array}{l}\text { Characteristics } \\
\text { Gender) }\end{array}$ & Frequency $(\mathrm{N}=250)$ & Percentage \\
\hline Male & 166 & 66.4 \\
\hline Female & 84 & 33.6 \\
\hline
\end{tabular}

A total 250 filled questionnaires were received from library professionals across Pakistan. Of these, 166 respondents (66.4\%) were male and 84 $(33.6 \%)$ were female. With respect to their age, three categories were formed: those who were less than 31 years of age were 51 (20.4\%), the age group between 31 and 40 was composed of 134 respondents (53.6\%) and this is the largest group whereas those who were more than 40 years of age were $65(26.0 \%)$.

\section{Name of Degree Awarding Province/Federal Capital}

There are one or more library schools in all the four provinces and federal capital Islamabad. These schools professionally train the librarians and award them degrees from postgraduate to doctorate level. The professionals rendering their services in the libraries at home or abroad are the graduates of these schools.

Table 3: Province of obtaining professional degree

\begin{tabular}{|l|c|c|}
\hline $\begin{array}{l}\text { Professional Degree acquired } \\
\text { from: }\end{array}$ & Frequency $(\mathbf{N}=250)$ & Percentage \\
\hline Punjab & 97 & 38.8 \\
\hline KPK & 67 & 26.8 \\
\hline Sindh & 46 & 18.4 \\
\hline Federal capital, Islamabad & 24 & 9.6 \\
\hline Baluchistan & 16 & 6.4 \\
\hline
\end{tabular}

The universities from where the respondents got professional degrees are located in all four provinces, and federal capital, Islamabad. Of them, 97 (38.8\%) belonged to Punjab, 67 (26.8\%) from Khyber PakhtoonKhawah, 46 
(18.4\%) belonged to Sindh, 24 (9.6\%) represented Islamabad, and remaining $16(6.4 \%)$ from Baluchistan. Although they got their professional education from the universities of above four provinces and federal capital but they are working in a different or same area.

\section{Highest Professional Degree obtained}

All the professionals working in different capacities and positions are holding degrees from Masters to Doctorate. The following table shows the highest degree they have obtained:

Table 4: Professional Degree obtained by the respondents

\begin{tabular}{|l|c|c|}
\hline $\begin{array}{l}\text { Highest Professional } \\
\text { Degree }\end{array}$ & Frequency $(\mathbf{N}=250)$ & Percentage \\
\hline MLIS & 169 & 67.6 \\
\hline MLS & 27 & 10.8 \\
\hline MS & 18 & 7.2 \\
\hline M.Phil & 24 & 9.6 \\
\hline Ph.D & 12 & 4.8 \\
\hline
\end{tabular}

The highest degree the respondents acquired included MLS, MLIS, MS (in Lib \& Inf. Sc.), M.Phil. (LIS), and Ph.D. (LIS). Although MLS and MLIS are the same level degrees but those who passed out before 1980-85, hold the degree of MLS whereas the rest is possessing MLIS. 169 respondents (67.6\%) have MLIS degree, 27 respondents (10.8\%) hold MLS degree, 18 (7.2\%) are MS (LIS) degree holders, 24 respondents (9.6\%) hold M.Phil. degree whereas only 12 (4.8\%) are holding Ph.D. (LIS) degree.

\section{Type of Library of the participants}

Primarily, there are four types of library viz. academic, national, public, and special. The graduates of library schools are providing professional services in all types of library.

Table 5: Type of Library the participants working in

\begin{tabular}{|l|c|c|}
\hline Type of Library & Frequency $(\mathrm{N}=250)$ & Percentage \\
\hline Academic & 130 & 52.0 \\
\hline Special & 59 & 23.6 \\
\hline Public & 42 & 16.8 \\
\hline National & 19 & 7.6 \\
\hline
\end{tabular}


As far as the type of library is concerned, most of the respondents are working in academic libraries. A total 130 (52.0\%) respondents belong to academic libraries, 59 (23.6\%) from different special libraries, 42 (16.8\%) respondents are from public libraries, and 19 (7.6\%) from National Library of Pakistan.

\section{Working Experience}

As the targeted population of this research comprises all library professionals irrespective of their professional experience, from junior most to senior most working professionals took part. Following four categories were developed to show the years of their involvement in the profession.

\section{Table 6: Working experience of the respondents}

\begin{tabular}{|l|c|c|}
\hline Working Experience & Frequency $(\mathbf{N}=250)$ & Percentage \\
\hline $1-5$ years & 53 & 21.2 \\
\hline $6-10$ years & 90 & 36.0 \\
\hline $11-15$ years & 48 & 19.2 \\
\hline$>15$ years & 59 & 23.6 \\
\hline
\end{tabular}

The targeted population was composed of professionals having working experience of different years. This experience has been categorized into: 1-5 years, 6-10 years, 11-15 years and more than 15 years. There were 53 participants (21.2\%) having experience of 1-5 years and they were comparatively young professionals working at junior positions. In the category of 6-10 years of experience, the number of participants was 90 (36.0\%). Professionals with relatively plentiful experience and senior position had working experience from 11-15 years and among the total participants of the study, their number was 48 (19.2\%). Those who fall in the last category of more than 15 years of experience were working at the positions of senior librarian, chief librarian or head of the department. They had a vast professional experience and were well-versed with all the activities and functions of a library. The number of such respondents was 59 (23.6\%).

\section{Courses studied at Postgraduate Level}

Different courses of compulsory and optional nature are offered by all the library schools. All the students study the core and compulsory courses whereas some courses are opted by the students according to their interest. 
Table 7: Courses studied at Postgraduate level

\begin{tabular}{|l|c|c|}
\hline $\begin{array}{l}\text { No of course studied at } \\
\text { Masters level }\end{array}$ & Frequency $(\mathbf{N}=250)$ & Percentage \\
\hline $6-10$ & 106 & 42.4 \\
\hline $11-18$ & 92 & 36.8 \\
\hline More than 18 & 52 & 20.8 \\
\hline
\end{tabular}

Answering the question about total number of courses they studied, the respondents gave replies showing different number of courses. There were $106(42.4 \%)$ respondents who studied 6-10 courses in all. Those who studied 11-18 courses were 92 (36.8\%) whereas the lowest number of population comprised those who studied more than 18 courses and they were 52 $(20.8 \%)$ respondents.

\section{Compulsory Courses studied}

The students are required to study the compulsory and core courses to fulfill the requirements of degree. These courses provide basic and essential knowledge on the subject which help in strengthening the profession. Almost equal and same number of compulsory courses is offered by all the library schools with some exceptions.

Table 8: No. of compulsory courses studied

\begin{tabular}{|l|c|c|}
\hline $\begin{array}{l}\text { No of compulsory } \\
\text { courses }\end{array}$ & Frequency $(\mathrm{N}=250)$ & Percentage \\
\hline $4-10$ & 134 & 53.6 \\
\hline $11-16$ & 72 & 28.8 \\
\hline More than 16 & 44 & 17.6 \\
\hline
\end{tabular}

To the question about the number of compulsory courses offered to them, there are three categories of the respondents: those who were taught 4-10 compulsory courses included 134 (53.6\%), 11-16 compulsory courses were studied by 72 respondents (28.8\%) whereas there were 44 respondents $(17.6 \%)$ who were offered more than 16 compulsory courses.

\section{Optional Courses studied}

A variety of optional courses are included in the curricula of all library schools. Although majority of such courses are common in all universities but 
there are some courses which have been designed to meet the local market needs.

Table 9: No. of optional courses studied

\begin{tabular}{|l|c|c|}
\hline $\begin{array}{l}\text { No of optional } \\
\text { courses }\end{array}$ & Frequency $(\mathbf{N}=250)$ & Percentage \\
\hline $0-3$ & 149 & 59.6 \\
\hline $4-6$ & 101 & 40.4 \\
\hline
\end{tabular}

Regarding the question of optional courses, 149 (59.6\%) respondents replied for $0-3$ courses whereas the remaining 101 respondents (40.4\%) studied 4-6 optional courses.

\section{Optional courses in the curricula}

Combination of compulsory and optional courses is the integral part of any curriculum. Library and Information Science curriculum is also composed of a reasonable ratio of both the groups. The optional courses of Literature/Information Sources and Libraries and Librarianship provide specialization in specific field of literature and libraries whereas the incumbent, who had studied any of these optional courses, possesses the basic and core knowledge of other literatures and libraries which he/she had not studied.

\section{Optional courses of Literature/Information Sources}

One major category of optional courses is Literature or Information Sources on different fields as described here in the table:

Table 10: Optional Courses of literature/information sources studied by the respondents

\begin{tabular}{|l|c|c|}
\hline Courses & Frequency(N = 250) & Percentage \\
\hline Humanities & & \\
\hline No & 170 & 68.0 \\
\hline Yes & 80 & 32.0 \\
\hline Science & $(\mathbf{N}=250)$ & \\
\hline No & 157 & 62.8 \\
\hline Yes & 93 & 37.2 \\
\hline Islam & $(\mathbf{N}=250)$ & \\
\hline No & 232 & 92.8 \\
\hline
\end{tabular}




\begin{tabular}{|l|c|c|}
\hline Yes & 18 & 7.2 \\
\hline Social science & $(\mathrm{N}=250)$ & \\
\hline No & 190 & 76.0 \\
\hline Yes & 60 & 24.0 \\
\hline Technology & $(\mathrm{N}=250)$ & \\
\hline No & 223 & 89.2 \\
\hline Yes & 27 & 10.8 \\
\hline Pakistan & $(\mathrm{N}=250)$ & \\
\hline No & 235 & 94.0 \\
\hline Yes & 15 & 6.0 \\
\hline
\end{tabular}

In almost all the library schools of the country, some optional subjects are offered to the final year students so that they can study the courses of their caliber, interest and ability. One of these optional subjects is Literature or/and information sources of Humanities/ Social Science/ Science/ Technology/ Islam/ Pakistan. Of these optional courses, the library schools are offering different combinations in different semesters. The analysis of the data indicates that the course of Literature of Humanities was studied by 80 respondents which is $32 \%$ of the total. Literature of Science was opted by 93 participants (37.2\%). Literature and Sources on Islam was studied by only 18 respondents which is $7.2 \%$. The counterpart courses of Humanities, Science and Islam are Literature and Sources on Social Science, Technology, and Pakistan which were opted by 60 (24\%), 27 (10.8\%), and 15 (6.0\%) participants respectively.

\section{Optional courses of Libraries/Librarianship}

Although a wide range of optional courses on libraries and librarianship is offered to the students as a specialization course in the final year but the collected data shows only six optional courses studied by the participants viz. Academic Libraries, Public Libraries, Special Libraries, School Libraries, Comparative and International Librarianship, and Medical Librarianship. This group of optional courses is taught in almost all the library schools with some amendments or additions. 
Table 11: Optional Courses of libraries/librarianship studied by the respondents

\begin{tabular}{|c|c|c|}
\hline Courses & Frequency & Percentage \\
\hline Academic Libraries & $(N=250)$ & \\
\hline No & 75 & 30.0 \\
\hline Yes & 175 & 70.0 \\
\hline Public Libraries & $(\mathrm{N}=250)$ & \\
\hline No & 203 & 81.2 \\
\hline Yes & 47 & 18.8 \\
\hline Special Libraries & $(\mathrm{N}=250)$ & \\
\hline No & 210 & 84.0 \\
\hline Yes & 40 & 16.0 \\
\hline Children Libraries & $(\mathrm{N}=250)$ & \\
\hline No & 74 & 29.6 \\
\hline Yes & 176 & 70.4 \\
\hline $\begin{array}{l}\text { Comparative \& } \\
\text { International } \\
\text { Librarianship }\end{array}$ & $(N=250)$ & \\
\hline No & 216 & 86.4 \\
\hline Yes & 34 & 13.6 \\
\hline Medical Libraries & $(\mathrm{N}=250)$ & \\
\hline No & 210 & 84.0 \\
\hline Yes & 40 & 16.0 \\
\hline
\end{tabular}

Majority of the respondents opted Academic Libraries and Children Libraries during their studies. 176 (70.4\%) participants studied children libraries and $175(70.0 \%)$ of total participants studied academic libraries, whereas Public Libraries and Special Libraries were also studied by 47 (18.8\%) and 40 $(16 \%)$ respondents respectively. The counterpart of these courses are Comparative \& International Librarianship and Medical Libraries which were studied respectively by 34 (13.6\%) and 40 (16.0\%) respondents.

\section{Suitability of a professional with different courses studied}

Although different optional courses are offered either for specialization or keeping in view the tendency of the students but this does not confine them or refrain them from selecting a professional field. As they have basic and core knowledge of librarianship so can cope with any type of collection in 
their library. Despite this fact, the professionals/respondents have different points of view:

Table 12: Suitability/Unsuitability of an incumbent in an organization

\begin{tabular}{|l|c|c|}
\hline Characteristics & Frequency(N =250) & Percentage \\
\hline $\begin{array}{l}\text { Suitability of a person in } \\
\text { an organization with a } \\
\text { different type of } \\
\text { literature /librarianship } \\
\text { which he/she had not } \\
\text { studied }\end{array}$ & \\
\hline Fully Agreed & $\mathbf{7 1}$ & \\
\hline Partially Agreed & $\mathbf{1 3 4}$ & \\
\hline Not Agreed & $\mathbf{4 5}$ & $\mathbf{2 8 . 4}$ \\
\hline
\end{tabular}

Data indicates that the majority of the participants has reservations about the suitability of a person having background of courses studied and working in a different type of library containing another type of literature/information sources. $134(53.6 \%)$ respondents showed partial agreement with the suitability of such incumbent. $71(28.4 \%)$ respondents agreed absolutely and $45(18.0 \%)$ disagreed to the notion.

\section{Satisfaction with the MLIS course contents}

The courses taught at MLIS level are of advanced, specialized and slightly research nature aimed to prepare not only the quality librarians but also to produce such professionals who are ready to help and entertain research activities of the users of their library and to develop research interest in themselves. Majority of the respondents seem to be satisfied with the contents of the MLIS courses.

Table 13: Satisfaction with the MLIS course contents

\begin{tabular}{|l|c|c|}
\hline $\begin{array}{l}\text { Satisfaction with the } \\
\text { contents of the MLIS } \\
\text { courses }\end{array}$ & Frequency (N =250) & Percentage \\
\hline Highly satisfied & $\mathbf{8 0}$ & 32.0 \\
\hline Satisfied & 140 & 56.0 \\
\hline Somewhat Satisfied & 30 & 12.0 \\
\hline
\end{tabular}


As far as the satisfaction of the respondents about the subject contents of the courses they studied at MLIS was concerned, 80 respondents (32\%) were highly satisfied, 140 (56\%) were satisfied and 30 (12\%) were slightly satisfied. Hence the data shows that majority of the respondents is either satisfied or highly satisfied with the contents of the courses they studied.

\section{Opinion about courses of other universities}

Comparison of courses can simply be made when one has knowledge about the courses offered in other universities. This is possible only if the courses of other library schools have been gone through. The participants were inquired about it and they were also asked to mention the titles of the courses which enticed them as they have not studied the same.

\section{Awareness about the courses of other library schools}

A large number of the professionals are aware about the courses offered in other universities. They have shown interest in the strength and weaknesses of what they had studied and the same of the other universities.

Table 14: Having gone through the courses being taught by other universities of Pakistan

\begin{tabular}{|l|c|c|}
\hline Characteristics & $\begin{array}{c}\text { Frequency }(\mathbf{N}= \\
\text { 250) }\end{array}$ & Percentage \\
\hline $\begin{array}{l}\text { Knowledge about the curricula } \\
\text { of other universities }\end{array}$ & & \\
\hline No & 73 & 29.2 \\
\hline Yes & 177 & 70.8 \\
\hline
\end{tabular}

Majority of the respondents have gone through or have a glance on the courses offered by the library schools other than their own. 177 (70.8\%) have knowledge about such courses whereas 73 (29.2\%) respondents have not read the courses of other universities.

\section{Inspiration from the courses of other universities}

Some professionals have critical and research-oriented thinking and enhance their knowledge and ability to improve their professional services. For this purpose, they try to find out their shortcomings and inefficiencies by studying the courses of other library schools and some courses inspire and appeal them. 
Table 15: Stimulation developed by the courses of other universities

\begin{tabular}{|l|c|c|}
\hline Characteristics & $\begin{array}{c}\text { Frequency }(\mathrm{N}= \\
\text { 250) }\end{array}$ & Percentage \\
\hline $\begin{array}{l}\text { Development of stimulation } \\
\text { from other universities' } \\
\text { courses }\end{array}$ & & \\
\hline No & & \\
\hline Yes & 212 & 84.8 \\
\hline
\end{tabular}

Although a majority of the participants had gone through the courses of other universities for their satisfaction and interest but only few have got inspiration from those courses and they recommend those courses or some of the contents of the courses should also be offered by their universities. Only $38(15.2 \%)$ respondents were motivated by such courses whereas the remaining 212 (84.8\%) did not have any inspiration or motivation.

\section{Possibility of merging two or more courses}

Some of the courses being offered have similar nature or a few of the topics of the courses are correlated. A handful number of professionals feel such courses should be merged to avoid duplication.

Table 16: Opinion about merging of two or more courses

\begin{tabular}{|l|c|c|}
\hline $\begin{array}{l}\text { Opinion about merging of } \\
\text { any two or more courses }\end{array}$ & $\begin{array}{c}\text { Frequency (N = } \\
250)\end{array}$ & Percentage \\
\hline No & 184 & 73.6 \\
\hline Yes & 66 & 26.4 \\
\hline
\end{tabular}

Out of total population, only $66(26.4 \%)$ respondents showed their willingness to merge two courses whereas rest i.e. 184 (73.6\%) respondents were against the idea.

\section{Merging of Two or more Courses}

As very small number of respondents was in favour of merging two or more courses, they pointed out some of the courses which can be merged. 
Table 17: Title of courses to be merged

\begin{tabular}{|l|c|c|c|}
\hline Courses & $\begin{array}{c}\text { Responses } \\
\text { (N = 50) }\end{array}$ & $\begin{array}{c}\text { Percent } \\
\text { (Out of } \\
\text { N) }\end{array}$ & $\begin{array}{c}\text { Percent of } \\
\text { Cases (Out of } \\
\text { Total } \\
\text { Respondents) }\end{array}$ \\
\hline Classification \& Cataloguing & 20 & 40 & 8.0 \\
\hline $\begin{array}{l}\text { Information Sources \& } \\
\text { Information Tech. }\end{array}$ & 2 & 4 & 0.8 \\
\hline Research \& Networking & 2 & 4 & 0.8 \\
\hline Cataloguing \& Bibliography & 2 & 4 & 0.8 \\
\hline $\begin{array}{l}\text { Classification \& Reference } \\
\text { Services }\end{array}$ & 2 & 4 & 0.8 \\
\hline $\begin{array}{l}\text { Classification \& Advanced } \\
\text { Classification }\end{array}$ & 2 & 4 & 0.8 \\
\hline $\begin{array}{l}\text { Networking \& Management } \\
\text { \& Retrieval System }\end{array}$ & 2 & 4 & 0.8 \\
\hline $\begin{array}{l}\text { Collection Development \& } \\
\text { Reference Services }\end{array}$ & 4 & 8 & 0.8 \\
\hline $\begin{array}{l}\text { Public Library \& Library and } \\
\text { Society }\end{array}$ & 2 & 4 & 0.8 \\
\hline $\begin{array}{l}\text { History of Libraries \& } \\
\text { Bibliography }\end{array}$ & 2 & 4 & 4 \\
\hline $\begin{array}{l}\text { History of Libraries \& } \\
\text { Library and Society }\end{array}$ & 2 & 4 & 0.8 \\
\hline $\begin{array}{l}\text { Collection Development \& } \\
\text { Management of Libraries }\end{array}$ & 2 & 4 & 0.8 \\
\hline Indexing \& Bibliography & 2 & 4 & 0.8 \\
\hline Programing HTML \& LINEX & 2 & 4 & 0.8 \\
\hline JAVA \& KOHA & 2 & 4 & 0.8 \\
\hline
\end{tabular}

Majority of the responses (20 out of total 50) were about merging of Classification and Cataloguing. This response is 40 percent of the total responses by 8 percent population. The second group of courses to be merged is Collection Development and Reference Services, which was replied by 4 respondents which comes to 8 percent responses by 1.6 percent population. The other suggestions about merging of courses (as shown in the table) are insignificant. 


\section{Viewpoint about the nature of Masters' thesis}

At Masters' level, some of the students are inclined towards research and keeping in view their potential, they are offered to write a thesis/research project on any informative topic of their interest under the supervision of a teacher. Almost all the universities encourage their students to exhibit their research abilities. In some disciplines, thesis is compulsory for the fulfillment of the Master's degree but in some other disciplines, it is optional. The library professionals were inquired to give their point of view about the status of thesis:

Table 18: Opinion about nature of Masters' thesis

\begin{tabular}{|l|c|c|}
\hline Characteristics & $\begin{array}{c}\text { Frequency }(\mathrm{N}= \\
250)\end{array}$ & Percentage \\
\hline $\begin{array}{l}\text { Thesis should be compulsory } \\
\text { for all students }\end{array}$ & & \\
\hline No & 45 & 18.0 \\
\hline Yes & 205 & 82.0 \\
\hline Duration of thesis & Frequency $(\mathbf{N}=$ & Percentage \\
& $250)$ & 36.0 \\
\hline Two semesters & 90 & 26.4 \\
\hline One semesters & 66 & 34.0 \\
\hline One year & 85 & 3.6 \\
\hline Two year & 9 & Percentage \\
\hline Weightage of thesis & Frequency (N $=$ & 74.4 \\
\hline 100 Marks & $250)$ & 25.6 \\
\hline 200 Marks & 186 & 64 \\
\hline
\end{tabular}

Regarding the nature of Master's Thesis/Research Project as compulsory, 45 respondents $(18.0 \%)$ replied in negative whereas 205 respondents $(82.0 \%)$ were in favour of making it compulsory. About the duration of the thesis, 90 respondents (36.0\%) answered for 2 semesters, 66 (26.4\%) answered for one semester, 85 participants (34.0\%) replied for one academic year and remaining only 9 respondents (3.6\%) suggested the period of 2 years. About the marks of the thesis, $186(74.4 \%)$ recommended 100 marks whereas 64 respondents (25.6\%) replied for 200 marks. 


\section{Uniformed education and examination system}

All the library schools of Pakistan are producing library professionals with more or less same qualification and abilities. Although the library schools are governed by Higher Education Commission but they are independent in formulating the policies with respect to educational system, examination system etc. They have their statutory bodies of the respective universities which frame rules, regulations, and policies of their own. Except one library school of the country (Punjab University), all schools have uniformed nomenclature i.e. "Department of Library and Information Science" whereas Punjab University's department has, in the recent past, changed the name as "Department of Information Management". The Sindh University's department has some addition and named as "Department of Library \& Information Science and Archives Studies". The respondents have their views on same or different nomenclature and about the system of education and examinations:

Table 19: Viewpoint about uniformed system of education and examinations

\begin{tabular}{|l|c|c|}
\hline $\begin{array}{l}\text { Opinion about uniformity of the } \\
\text { nomenclature of the department of } \\
\text { LIS of all the universities }\end{array}$ & Frequency (N - 250) & Percentage \\
\hline No & $\mathbf{3 4}$ & $\mathbf{1 3 . 6}$ \\
\hline Yes & $\mathbf{2 1 6}$ & $\mathbf{8 6 . 4}$ \\
\hline $\begin{array}{l}\text { Opinion about uniformed system } \\
\text { of education and examination in all } \\
\text { the universities }\end{array}$ & Frequency (N- 250) & Percentage \\
\hline No & $\mathbf{3 1}$ & $\mathbf{1 2 . 4}$ \\
\hline Yes & $\mathbf{2 1 9}$ & $\mathbf{8 7 . 6}$ \\
\hline
\end{tabular}

About the similarity/uniformity of the nomenclature of the department of library and information science of all the universities of Pakistan, 216 respondents (86.4\%) were in favour of the question whereas the remaining $34(13.6 \%)$ replied in negative. Almost the same result was received when asked about the uniformed system of education and examinations in all the universities of Pakistan. 219 (87.6\%) respondents' answer was in affirmative whereas the response of $31(12.4 \%)$ was against the idea.

\section{Optional groups and courses}

As besides compulsories, there are some optional courses offered to the students by all library schools. From a group of optional courses, the 
students have to choose one according to their interest or tendency. There are several groups of optional courses and in each group; there are a number of courses to be opted. The participants exhibit their viewpoint about the sufficiency or insufficiency of these optional groups and courses.

Table 20: Opinion about optional groups and courses

\begin{tabular}{|l|c|c|}
\hline $\begin{array}{l}\text { Opinion about insufficiency of } \\
\text { groups of optional subjects }\end{array}$ & $\begin{array}{c}\text { Frequency (N - } \\
\mathbf{2 5 0}\end{array}$ & Percentage \\
\hline No & $\mathbf{8 6}$ & $\mathbf{3 4 . 4}$ \\
\hline Yes & $\mathbf{1 6 4}$ & $\mathbf{6 5 . 6}$ \\
\hline $\begin{array}{l}\text { Opinion about insufficiency of } \\
\text { subjects in existing groups }\end{array}$ & $\begin{array}{c}\text { Frequency (N - } \\
\mathbf{2 5 0}\end{array}$ & Percentage \\
\hline No & $\mathbf{1 4 8}$ & $\mathbf{5 9 . 2}$ \\
\hline Yes & $\mathbf{1 0 2}$ & $\mathbf{4 0 . 8}$ \\
\hline
\end{tabular}

When asked about the insufficiency of the number of groups of optional subjects, $164(65.6 \%)$ replied affirmatively whereas 86 respondents (34.4\%) had the opposite version. This indicates that according to $34.4 \%$ of the targeted population, the number of groups of optional subjects in the existing curricula of all the library schools is sufficient and rarely a group or two are required to be included in the curricula whereas the majority (65.5\%) deems a need to expand the groups of optional subjects.

\section{Key Findings}

- Majority of the participants studied optional courses of "Literature of Humanities", "Literature of Science", "Academic Libraries", and "Children Libraries".

- Majority of the participants was satisfied with the subject contents of the courses they studied.

- Majority of the participants declared courses of Indexing and Abstracting as non-implemented courses in profession.

- Majority of the participants was against merging of two or more courses.

- Majority was in favor of Master's Thesis as compulsory one.

- Majority was in favor of uniformed nomenclature of the departments of LIS and uniformed system of education and examinations.

- Majority recommended training of ICT. 


\section{Conclusion}

The education of library science (now library and information science) was started in 1956 from University of Karachi. At that time it was a one-year postgraduate program and gradually it was elevated to higher level and today has reached to Ph.D. Till 1982, five universities were offering programs in library science but later on, the number started increasing. The other universities of Pakistan, following the example of Karachi University, also started the programs and now nine public sector and three private sector universities of Pakistan are offering professional degree program in library and information science. Realizing the importance of library education, the private universities have started offering the program up to Ph.D.

Although the program had been started as one year postgraduate diploma in Library Science (PGD-LS), or DLS, or BLS, or equivalent but after some time, it had been converted into one more year as MLS, or MA in Library Science but in the recent years, due to the involvement of Higher Education Commission (HEC), emphasis was given to 4-year BS program (equivalent to M.A.). Some universities adopted the four-year program whereas some others continued with the two-year postgraduate program. Today, a few universities are practicing 2-year, some other 4-year, and some both the systems in parallel. As far as the system of education and examination is concerned, till the end of 2016, except two universities (Peshawar University and Baluchistan University) were practicing semester system whereas these universities were following annual system but with the start of 2017, Baluchistan University has also come in the mainstream and has adopted semester system and now only Peshawar University is practicing annual system.

The graduates of the universities who had/have two degrees of one year each (most commonly BLIS and MLIS) are in favor of continuation of these two separate programs as after successful completion of one year, if the student wants to drop for a reason or another, he/she can get a degree which would be useful for his/her career. Most of the working librarians support this practice and demand all the universities to follow the system.

The Higher Education Commission has developed LIS curriculum and, from time to time, revises it but the library schools, except one or two, develop their own curricula as per local requirements. The curricula of all Pakistani library schools are same with minor differences. All the universities are 
offering core courses to the students of BLIS or equivalent while specialized and elective courses are taught in next year.

Use of information and communication technology (ICT) in the libraries of Pakistan is passing through a transitory phase so the demand of ICT-based courses is very high. The library professionals, who graduated two decades ago are familiar with the technology and are using it to some extent to serve their clients. However, those who graduated earlier than that period, demanded that not only the course is to be included in the curricula but refresher courses be conducted for the folks like them. Another most demanding course to be included in the curricula is Communication Skills. People realize that the library professionals, like many other professionals, are lacking in noting, drafting, and communicating with their patrons due to lack of competencies. Verbal and written communication and professional correspondence is necessary to run the routines of a library, so the people should be trained in such a way that they can impressively represent their organization at different forums. Another thing which was emerged with respect to inclusion/exclusion of the courses to be studied was that the professionals want to study only those courses which are beneficial for them and applicable in their profession.

As far as elective courses of librarianship are concerned, the consensus was drawn that a professional can work in any type of library irrespective of the fact that he/she had studied another type of librarianship. Justification for this fact is that the professional had already studied the functions, services, collections, readers and responsibilities of all types of library, besides other professional courses, so the atmosphere of any type of library will not be strange for him/her.

Some of the professionals had also shown the quality of urge of learning. They remain inquisitive in search of learning new and unique things. When they think they had not studied something relevant to their field or profession, they try to seek which other university is offering the same thing. For this purpose, they study the courses of other library schools and hence keep themselves updated about the expertise of other universities. Some of the courses of other library schools also inspire them and they discuss it with their colleagues.

Since at master level, only the stereotype education is not imparted but the concept about research is also developed among the learners so they are 
encouraged to incline towards research projects, research paper, thesis, etc. This micro level study can develop research culture in academic institutions. To achieve the same purpose, Masters Research spread over two semesters of final year is been recommended. The students having interest in conducting research will opt a thesis against two courses of first and second semester under the guidance of a faculty member.

\section{Recommendations}

After meeting and interviewing the stakeholders and gathering opinions of professionals working across the country through questionnaires, the following courses or contents of courses have been identified which can be made the part of the LIS curricula:

- Information and knowledge management

- Project management

- Media library management

- Financial management

- Human resource management

- System analysis and management

- Metadata management

- Digital content management

- Digital repositories

- Digital libraries

- Design of digitally meditated information services

- Conceptual database design

- Network system administration

- E-subscription

- E-communication

- Data mining

- EndNote software

- Information architecture

- Information needs and use

- Content analysis

- Personality development

- Leadership skills

- Skill development

- Written and verbal communication skills

- $21^{\text {st }}$ century learning skills

- Teaching library users

- Information Literacy Instructions 
Jhss, Vol. 8, No. 2 , July to December, 2017

- Compulsory Master thesis

- Market-based library planning

- Research techniques

- Evidence-based training/learning

- Architecture of library building

- Archival preservation techniques

- Implementation of networking

- Functional English courses

- RDA

- Online cataloguing

- Basic statistics courses

- Internship 


\section{References}

Ameen, Kanwal. Challenges of preparing LIS professionals for leadership roles in Pakistan. Journal of education for Library and Information Science. 47(3).2006. pp. 200-217.

Curry, A. Canadian library and information science education trends and issues. Education for Information, 18 (4), 2002. pp. 325-337.

Haider, S. J. Teaching of cataloging and classification in Pakistan. Cataloging \& classification quarterly, 43. 2006. pp. 53-65.

Khan, M. Tufail and Mahmood, Khalid. A comparison of MLIS curricula taught in Pakistani library and information science schools with Higher Education Commission curriculum. Library Philosophy and Practice (e-journal). 2013. retrieved on 15-10-2013.

Mahmood, Khalid. LIS curriculum review using focus group interviews of employers. Library philosophy and practice (e-journal). 2012. retrieved on 6-7-2012.

Mallinson, Vernon. The Western European idea in education. European journal of education. 16(1), 1981. pp. 121-128.

Mangla, P.B. Contents and courses at the postgraduate level. Journal of Library and Information Science. 5(2), 1980. p.102. 
Jhss, Vol. 8, No. 2 , July to December, 2017

Ocholla, D.N. Review and revision of library and information science curriculum in South Africa University and usage of follow-up study and advancement scanning methods, 2000. Available: http://www.slib.ualberta.ca/cais/2000/ocholla.htm

Sabzwari, G.A. (1972). Library education and manpower needs in Pakistan. Pakistan library bulletin. IV(3-4). 1972. pp. 55-71.

Warraich, Nosheen Fatima. MLIS curriculum at Punjab University: perception and reflections. Library Philosophy and Practice (e-journal.) 2010. retrieved on 19-3-2010.

Yusuf, M. Critical view of the courses offered at library schools in Pakistan. PLA journal, 18. 1996. pp. 68-76. 